\title{
Evaluation of Loss in Vigour of the Dual Purpose French Guinea Fowl and Their Mixed Genetic Grade in Katsina, Nigeria
}

\author{
Elkana H., Gwaza D. S. * \\ Department of Animal Breeding, Physiology University of Agriculture, Nigeria
}

Copyright $\bigcirc 2019$ by authors, all rights reserved. Authors agree that this article remains permanently open access under the terms of the Creative Commons Attribution License 4.0 International License

\begin{abstract}
The effect of genetic grade (strain) on body weight and body linear measurements of the pure grade dual purpose French guinea fowl strain (116 birds) and their mixed genetic grade (32 birds) was determined using a linear mathematical model. Birds were raised under intensive system in Katsina state. Loss in vigour of the pure grade dual purpose French guinea fowl was calculated by difference. There was a significant $(P<0.05)$ effect of strain (genetic grade) on body weight and body linear measurements. The pure grade dual purpose French guinea fowl cocks and hens had significantly higher body weight and most body linear measurements than counterpart dual purpose mixed genetic grade guinea fowl cocks and hens. The pure grade dual purpose French guinea fowl cocks and hens had lower coefficients of variation (7.76 and $9.60 \%$ ) than the dual purpose guinea fowl cocks and hen mixed genetic grades (13.11 and $13.54 \%$ ). The dual purpose mixed genetic grade guinea fowl cocks and hens had longer helmet length than counterpart pure grade dual purpose French guinea cocks and hens. Strain (genetic grade) had no effect on tail length of guinea hens. There were high loss of vigour (56.25 and $57.69 \%$ ) of helmet thickness followed by (28.82 and $37.38 \%$ ) for body weight of the dual purpose French guinea fowl cocks and hens. Body length (3.76 and $0.56 \%)$ and thigh length (4.22 and $1.85 \%)$ respectively for guinea fowl cocks and hens, were the morphometric traits that had the lowest reduction in vigour among all quantitative traits evaluated. The dual purpose French guinea fowl and their mixed genetic grade had higher body weight than counterpart local guinea fowl strains. Introduction of the dual purpose French guinea fowl into the tropics can aid the diversification of rural poultry production.
\end{abstract}

Keyword Guinea Fowl, Katsina, Measurements

\section{Introduction}

The common sources of egg and meat are the layer and the broiler chickens whose production environment and managements needs are expensive as well as the needs for professional expertise [1]. At such, prevalent cases of animal protein deficiency are common among most rural populaces [2] who don't have sufficient economics for improved standard of living. Therefore the quest to meet up with the demand for daily animal protein (meat and egg) intake especially among most rural populace will require diversification of meat and egg production avenues [3] Hence the need to explore the use of species that has peculiar attributes: able to survive satisfactorily under free range management, good economic return with minimum cost of production and prolificacy [4]. The importance of Guinea fowl in improving nutritional needs and standard of living among most rural household can never be over emphasized. Guinea fowl has promising potentials as world's alternative poultry enterprise [5].

The French guinea fowl has the potential for rural production, the cost of production is low compared to broiler and layer chicken high cost of production [6]. The birds are also known for higher resistance to poultry diseases, higher annual egg output, and low mortality rate when compared to the chickens [7]. Hence, the dual purpose French guinea fowl strain, owing to its genetic credibility for meat and egg production would be an appropriate choice.

Therefore information on body biometry evaluation of the dual purpose French guinea fowl strain and their mixed genetic grade under semi-arid climate will be a useful guide towards its introduction into other zones of Nigeria to diversify poultry production for alleviation of protein deficiency and poverty among the rural and the urban populace in Nigeria. Information on phenotypic values of the dual purpose French guinea fowl and their mixed genetic grade may be useful to subsistence farmers with 
who chances of rebreeding and cross breeding with local strain. The study was designed to evaluate body weight and body linear measurements of the dual purpose French guinea fowls and their mixed genetic grade with respect to its potential for introduction into the southern guinea savannah of Nigeria. As well as to assess loss in vigour of the dual purpose French guinea fowl due to crossbreeding with local indigenous guinea fowl cocks.

\section{Materials and Methods}

\subsection{Location of the Study}

The experiment was conducted in Katsina state Katsina is situated in North West Region of Nigeria, within the tropic region of the world between latitude $12^{\circ} 59^{\circ} \mathrm{N} /$ longitude $7^{\circ} 36 \mathrm{E}$ and latitude $12.983^{\circ} \mathrm{N}$ and $7.600^{\circ} \mathrm{E}$ of the $\mathrm{Gr}$ eenwich Meridian (GMT) with altitude of 182.82 to 457 meters above sea level [8]. According to Koppen climate classification system, Katsina has a hot semi-arid climate [9]. The annual rainfall is short and ranges between $500-800 \mathrm{~mm}$, the temperature fluctuates between $21^{\circ} \mathrm{C}$ and $35^{\circ} \mathrm{C}$, the area experiences relative humidity variations ranges of $20 \%$ to $40 \%$ in January and then rises to $80 \%$ in the rainy season [10].

\subsection{Management of the Experimental Birds, Experimental Design and Procedure}

The dual purpose French guinea fowls (DPFG) were from flocks of mature birds imported from France at day old and raised under intensive management. The dual purpose French guinea fowl mixed genetic grade (DMFG) were from crossing of the dual purpose French guinea fowl hens with the local indigenous guinea fowl cocks. Birds were fed commercial layer diet twice daily (morning and evening) and water was provided adlibitum

The procedures for data collection were taken as described as follows described by [11]. Body linear measurements were taken on beak length, shank length, thigh length, keel length, body length, wing span, wattle length, head length, helmet length, helmet thickness, chest circumference and tail length and live body weight at maturity (10 months). Body linear measurements and body weight taken using a plastic rule, vernier caliper, flexible measuring tape and a weighing scale as applicable to the body linear traits whereas a weighing scale was used to determine live body weight

\subsection{Data Analysis}

Descriptive statistics and analysis of variance of the parameters measured was done using Statistical package for the social sciences [12].

The model for estimation of body weight and body linear measurements is presented thus: $\mathrm{Y}_{\mathrm{ijk}}=\mu+\mathrm{X}_{\mathrm{i}}+\mathrm{S}_{\mathrm{j}}+\mathrm{e}_{\mathrm{ijk}}$ Where:

$\mathrm{Y}_{\mathrm{ijk}}=$ observation on the $\mathrm{k}^{\text {th }}$ individual of the $\mathrm{j}^{\text {th }}$ strain and the $i^{\text {th }}$ sex

$\mu=$ overall mean in the population

$X_{i}=$ effect of the $i^{\text {th }}$ sex

$\mathrm{S}_{\mathrm{j}}=$ effect of the $\mathrm{j}^{\text {th }}$ strain

$\mathrm{e}_{\mathrm{ijk}}=$ residual random error with mean zero and variance that of the population

\subsection{Loss in Vigour Due to Crossbreeding of Dual Purpose Guinea Fowls with Local Birds}

This was computed as the difference between the mean of the pure grade French guinea fowl and the mean of the dual purpose mixed genetic as shown below.

$$
\mathrm{V} \downarrow=\mu \mathrm{PG}-\mu \mathrm{MG}
$$

Where:

$\mathrm{V} \downarrow=$ loss in vigour

$\mu \mathrm{PG}=$ Mean of the pure grade parents of the dual purpose guinea fowls

$\mu \mathrm{MG}=$ Mean of the dual purpose mixed genetic grade

\subsection{Reduction in Vigour (\%) Relative to the Average Values of the Pure Grade Parent Stocks}

This was express as loss in vigour as a percentage of the mean of pure grade parents of the dual purpose guinea fowl.

$$
\mathrm{RV} \downarrow(\%)=\frac{\mathrm{V} \downarrow}{\mu \mathrm{PG}} \times 100
$$

Where:

$\mathrm{RV} \downarrow(\%)=$ Percent reduction in vigour relative to the pure grade (P1)

$\mathrm{V} \downarrow=$ loss in hybrid vigour

$\mu \mathrm{PG}=$ Mean of the pure grade parents of the dual purpose guinea fowls

\section{Result}

\subsection{Effect of Strain on Body Weight of DPFG and DMFG}

There were significant $(\mathrm{P}<0.05)$ differences due to strains effect on average body weight of birds. The DPFG cocks and hens were significantly $(\mathrm{P}<0.05)$ higher in body weight than the DMFG cocks and hens as presented in table 1 .

\subsection{Effect of Strain on Body Linear Measurements of DPFG and DMFG}

In table 2, the DPFG cocks were significantly $(\mathrm{P}<0.05)$ longer in beak length, shank length, wing span, chest 
circumference, claw length, tail length, neck length, body length, wattle length, keel length, head length and helmet thickness than the DMFG. There was no significant ( $\mathrm{P}>$ 0.05 ) difference due to strain (genetic grade) effect on the mean thigh length between the DPFG cocks and the DMFG. The DMFG cocks were significantly $(\mathrm{P}<0.05)$ higher in helmet length than counterpart DPFG cocks as presented in table 2.

The DPFG hens had significantly $(\mathrm{P}<0.05)$ longer beak length, shank length, wing span, chest circumference, length, neck length, wattle length, keel length, head length and helmet thickness than counterpart DMFG guinea hens. However, there was no significant $(\mathrm{P}>0.05)$ effect due to strain on thigh length, tail length and body length. The DMFG had significantly $(P<0.05)$ longer in mean helmet length than DPFG hens as presented in table 3.

\subsection{Loss in Vigour of $f 1$ Dual DMFG}

The DMFG cocks had loss vigour relative to the DPFG cocks on the following body traits: beak length, shank length, thigh length, wing span, chest circumference, tail length, neck length, body length, wattle length, keel length, head length, helmet thickness and body weight. There was however an increase in helmet length DMFG cocks as presented in table 4.

The DMFG hens had loss vigour relative to the DPFG hens on the following body traits: beak length, shank length, thigh length, wing span, chest circumference, for neck length, body length, wattle length, keel length, head length, helmet thickness and body weight. There was however an increase in tail length and helmet of the DMFG hens as presented in table 4 .

\section{Results}

Table 1. Effect of strain on body weight (kg) of DPFG and DMFG

\begin{tabular}{|c|c|c|c|c|}
\hline Strain & \multicolumn{3}{|c|}{ Body weight \pm SE } & \\
\hline & Male & $\mathrm{CV}$ & Female & $\mathrm{CV}$ \\
\hline DPFG & $\begin{array}{c}2.88^{\mathrm{a}} \pm \\
0.03\end{array}$ & 7.76 & $3.05^{\mathrm{a}} \pm$ & 9.60 \\
& 0.03 & \\
\hline DMFG & $\begin{array}{c}2.05^{\mathrm{b}} \pm \\
0.07\end{array}$ & 13.11 & $1.91^{\mathrm{b}} \pm$ & 13.54 \\
& 0.06 & \\
\hline
\end{tabular}

$\mathrm{a} \mathrm{b}=$ Means with different superscripts differ significantly $(P<0.05)$ within the columns due to strain effect

$\mathrm{DPFG}=$ Dual purpose French guinea fowl

$\mathrm{DMFG}=$ Dual purpose mixed genetic grade

C.V $=$ Coefficient of variation

$\mathrm{SE}=$ Standard error
Table 2. Effect of Strain on BLM of the DPFG and the DMFG cocks

\begin{tabular}{|c|c|c|c|}
\hline Parameters & DPFG cocks & DMFG cocks & $P$-Value \\
\hline ChC & $38.97^{\mathrm{a}} \pm 0.15$ & $33.81^{\mathrm{b}} \pm 0.29$ & 0.000 \\
\hline BoL & $27.68^{\mathrm{a}} \pm 0.15$ & $26.64^{\mathrm{b}} \pm 0.32$ & 0.01 \\
\hline ShL & $8.88^{\mathrm{a}} \pm 0.06$ & $8.21^{\mathrm{b}} \pm 0.13$ & 0.000 \\
\hline ThL & $13.73 \pm 0.12$ & $13.15 \pm 0.22$ & 0.251 \\
\hline $\mathrm{NkL}$ & $17.41^{\mathrm{a}} \pm 0.10^{\mathrm{a}}$ & $15.58^{\mathrm{b}} \pm 0.18$ & 0.000 \\
\hline $\mathrm{KL}$ & $13.90^{\mathrm{a}} \pm 0.08$ & $13.02^{\mathrm{b}} \pm 0.16$ & 0.000 \\
\hline $\mathrm{WnS}$ & $52.62^{\mathrm{a}} \pm 0.36$ & $48.22^{\mathrm{b}} \pm 0.70$ & 0.000 \\
\hline $\mathrm{WtL}$ & $3.19^{\mathrm{a}} \pm 0.05$ & $2.19^{\mathrm{b}} \pm 0.10$ & 0.000 \\
\hline $\mathrm{BkL}$ & $2.50^{\mathrm{a}} \pm 0.02$ & $2.36^{\mathrm{b}} \pm 0.02$ & 0.000 \\
\hline $\mathrm{HdL}$ & $8.07^{\mathrm{a}} \pm 0.05$ & $7.74^{\mathrm{b}} \pm 0.09$ & 0.000 \\
\hline $\mathrm{HeL}$ & $1.88^{\mathrm{b}} \pm 0.04$ & $2.21^{\mathrm{a}} \pm 0.07$ & 0.000 \\
\hline $\mathrm{HeT}$ & $1.123^{\mathrm{a}} \pm 0.03$ & $0.49^{\mathrm{b}} \pm 0.06$ & 0.000 \\
\hline TaL & $16.10^{\mathrm{a}} \pm 0.14$ & $15.00^{\mathrm{b}} \pm 0.26$ & 0.000 \\
\hline
\end{tabular}

$\mathrm{a} b=$ means with different superscripts differ significantly $(P<0.05)$ due to strain effect on $\mathrm{BLM}$ within a sex $\mathrm{ChC}=$ chest circumference, $\mathrm{BoL}=$ body length, $\mathrm{ShL}=$ shank length, $\mathrm{ThL}=$ thigh length, $\mathrm{Nkl}=$ neck length, $\mathrm{KL}=$ keel length, $\mathrm{WnS}=$ wing span, $\mathrm{WtL}=$ wattle length, $\mathrm{BkL}=$ beak length, $\mathrm{HdL}=$ head length, $\mathrm{HeL}=$ helmet length,

$\mathrm{HeT}=$ helmet thickness, $\mathrm{TaL}=$ tail length,

DPFG $=$ Dual purpose French guinea fowl,

$\mathrm{DMFG}=$ Dual purpose mixed genetic grade,

$\mathrm{BLM}=$ Body linear measurement

Table 3. Effect of Strain on BLM of the DPFG and the DMFG hens

\begin{tabular}{|c|c|c|c|}
\hline Parameters & DPFG hens & DMFG hens & $P$-Value \\
\hline ChC & $37.06^{\mathrm{a}} \pm 0.14$ & $31.04^{\mathrm{b}} \pm 0.26$ & 0.000 \\
\hline BoL & $24.86 \pm 0.14$ & $24.72 \pm 0.17$ & 0.795 \\
\hline ShL & $7.64^{\mathrm{a}} \pm 0.05$ & $7.23^{\mathrm{b}} \pm 0.09$ & 0.008 \\
\hline $\mathrm{ThL}$ & $12.40^{\mathrm{a}} \pm 0.10$ & $12.17^{\mathrm{b}} \pm 0.12$ & 0.114 \\
\hline $\mathrm{NkL}$ & $16.2^{\mathrm{a}} \pm 0.90$ & $15.33^{\mathrm{b}} \pm 0.16$ & 0.000 \\
\hline $\mathrm{KL}$ & $12.60^{\mathrm{a}} \pm 0.07$ & $12.04^{\mathrm{b}} \pm 0.14$ & 0.002 \\
\hline $\mathrm{WnS}$ & $49.76^{\mathrm{a}} \pm 0.32$ & $45.27^{\mathrm{b}} \pm 0.60$ & 0.000 \\
\hline $\mathrm{WtL}$ & $2.24^{\mathrm{a}} \pm 0.05$ & $1.76^{\mathrm{b}} \pm 0.09$ & 0.000 \\
\hline $\mathrm{BkL}$ & $2.42^{\mathrm{a}} \pm 0.02$ & $2.17^{\mathrm{b}} \pm 0.02$ & 0.000 \\
\hline $\mathrm{HdL}$ & $7.21^{\mathrm{a}} \pm 0.04$ & $6.83^{\mathrm{b}} \pm 0.08$ & 0.000 \\
\hline $\mathrm{HeL}$ & $1.15^{\mathrm{b}} \pm 0.03$ & $1.62^{\mathrm{a}} \pm 0.06$ & 0.000 \\
\hline $\mathrm{HeT}$ & $0.93^{\mathrm{a}} \pm 0.03$ & $0.44^{\mathrm{b}} \pm 0.05$ & 0.000 \\
\hline TaL & $13.93 \pm 0.12$ & $14.27 \pm 0.24$ & 0.029 \\
\hline
\end{tabular}

$\mathrm{a} b=$ means with different superscripts differ significantly $(P<0.05)$ due to strain effect on $\mathrm{BLM}$ within a sex $\mathrm{ChC}=$ chest circumference, $\mathrm{BoL}=$ body length, $\mathrm{ShL}=$ shank length, $\mathrm{ThL}=$ thigh length, $\mathrm{Nkl}=$ neck length, $\mathrm{KL}=$ keel length, $\mathrm{WnS}=$ wing span, $\mathrm{WtL}=$ wattle length, $\mathrm{BkL}=$ beak length, $\mathrm{HdL}=$ head length, $\mathrm{HeL}=$ helmet length

$\mathrm{HeT}=$ helmet thickness, $\mathrm{TaL}=$ tail length

DPFG $=$ Dual purpose French guinea fowl

$\mathrm{DMFG}=$ Dual purpose mixed genetic grade

$\mathrm{BLM}=$ Body linear measurement 
Table 4. Loss in vigour of DMFG cocks and hens relative to DPFG cocks and hens

\begin{tabular}{|c|c|c|c|c|}
\hline \multirow[t]{2}{*}{ Parameters } & \multicolumn{2}{|c|}{ Guinea fowl cocks } & \multicolumn{2}{|c|}{ Guinea fowl hens } \\
\hline & $\mathrm{V} \downarrow$ & $\mathrm{RV} \downarrow(\%)$ & $\mathrm{V} \downarrow$ & $\mathrm{RV} \downarrow(\%)$ \\
\hline $\mathrm{ChC}$ & 5.16 & 13.24 & 6.02 & 16.24 \\
\hline $\mathrm{BoL}$ & 1.04 & 3.76 & 0.14 & 0.56 \\
\hline ShL & 0.67 & 7.55 & 0.41 & 5.37 \\
\hline ThL & 0.58 & 4.22 & 0.23 & 1.85 \\
\hline NkL & 1.83 & 10.51 & 0.87 & 5.37 \\
\hline $\mathrm{KL}$ & 0.88 & 6.33 & 0.56 & 4.44 \\
\hline WnS & 4.40 & 8.36 & 4.49 & 9.02 \\
\hline WtL & 1.00 & 31.35 & 0.48 & 21.42 \\
\hline $\mathrm{BkL}$ & 0.14 & 5.60 & 0.25 & 10.33 \\
\hline $\mathrm{HdL}$ & 0.33 & 4.09 & 0.38 & 5.27 \\
\hline $\mathrm{HeL}$ & -0.33 & -17.55 & -0.47 & -40.87 \\
\hline $\mathrm{HeT}$ & 0.63 & 56.25 & 0.49 & 52.69 \\
\hline $\mathrm{TaL}$ & 1.10 & 6.83 & -0.34 & -2.44 \\
\hline \multicolumn{5}{|l|}{ Weight } \\
\hline BW & 0.83 & 28.82 & 1.14 & 37.38 \\
\hline
\end{tabular}

$\mathrm{V} \downarrow=$ loss in vigour

$\mathrm{RV} \downarrow(\%)=$ Percent reduction in vigour relative to the pure grade (P1)

$\mathrm{ChC}=$ chest circumference, $\mathrm{BoL}=$ body length, $\mathrm{ShL}=$ shank length, $\mathrm{ThL}=$ thigh length, $\mathrm{Nkl}=$ neck length, $\mathrm{KL}=$ keel length, $\mathrm{WnS}=$ wing span, $\mathrm{WtL}=$ wattle length, $\mathrm{BkL}=$ beak length, $\mathrm{HdL}=$ head length, $\mathrm{HeL}=$ helmet length $\mathrm{HeT}=$ helmet thickness, $\mathrm{TaL}=$ tail length

$\mathrm{BW}=$ body weight, $\mathrm{BLM}=$ Body linear measurement

\section{Discussion}

\subsection{Body Weight}

DPFG cocks and hens weighed more than their counterpart DMFG cocks and hens. Higher body weight of the DPFG over the DMFG could be due to genetic superiority and high vigour for body weight of the DPFG compared to the DMFG that would lose half of the vigour at every generation of crossbreeding the commercial line. The pure grade dual purpose French broiler guinea fowls had higher body weight than the Pearl guinea fowls [13]; $1.124-1.1345 \mathrm{~kg}$ for the Nigeria indigenous guinea fowls [14], $1.208 \mathrm{~kg}$ for the indigenous guinea fowls in the middle belt, Nigeria [15]; $1.1 \mathrm{~kg}$ for indigenous guinea fowls in Benin [16], and $1.48 \mathrm{~kg}$ for the Zimbabwean guinea fowls [17]. Higher body weight of the DPFG as opposed to the unimproved tropical strains could be attributed to selection for genetic improvement of the strain for higher body weight.

The DMFG had lower body weight than the DMFG. This indicated a reduction in body weight due to genetic dilution by rebreeding and crossing of the dual purpose French broiler guinea with the local indigenous strain. The DMFG at (> 10 months) had higher body weight than the indigenous guinea fowls [14], $1.208 \mathrm{Kg}$. for indigenous guinea fowls in the middle belt Nigeria [15] and $1.48 \mathrm{~kg}$ for the Zimbabwean guinea fowls [17]. Higher body weight of the DMFG over the unimproved tropical strains could be due to derived advantages due to upgrade in the genetic make-up attained by crossbreeding local stocks with the DPFG hens compared to these unimproved local strains. Body weight of the DMFG cocks in this study was higher than the range $1.927-2.043 \mathrm{~kg}$ reported for the Pearl guineas [13] whereas guinea hens were lower than the reported range.

The DPFG hens had higher body weight than the DPFG cocks. This has agrees with [13] who reported that guinea hens were superior in average body weight $(2.043 \mathrm{Kg})$ over guinea cocks $(1.927 \mathrm{Kg})$ and [18] who reported $2165 \pm$ 91.9 and $2279 \pm 74.7(\mathrm{~g})$ for male and female French guineas. The higher body weight of guinea fowl hens over cocks could be due to genetic improvement, weights of the female reproductive organs which are not found in guinea cocks. Thus, higher body weight of the DPFG hens may also be a reflection of a well-developed strain for egg production and egg size that allow guinea hens ability of high and heavy egg production.

Sex had no effect on mean body weight of the DMFG cocks and guinea hens. This agrees with [6] who reported that mean body weights of male and female guinea fowls $(1.3125$ and $1.304 \mathrm{Kg})$ were similar.

\subsection{Body Linear Measurements}

\subsubsection{Chest Circumference}

Chest circumference of the DPFG cocks and hens were comparatively longer than those of mature indigenous guinea fowls $34.23 \pm 0.19 \mathrm{~cm} \mathrm{[19];} 30.47 \pm 0.38,30.00 \pm$ 0.66 and $30.10 \pm 0.40 \mathrm{~cm}$ for the indigenous pearl, ash and black guinea fowls [20] and the reported values (31.3 and $30.9 \mathrm{~cm}$ ) for the pearl grey guinea fowls by [21]. The longer chest circumference of the strain over indigenous birds was due to the genetic improvement for large body size and faster tissue accretion for meat and egg production.

The DMFG e had higher mean chest circumference value than the indigenous pearl, ash and black guinea fowls respectively [20] and the range $30.9-31.3 \mathrm{~cm}$ reported for the pearl grey guinea fowl by [21]. The average chest circumference of the DMFG in was shorter than indigenous guinea fowls $35.37 \pm 0.35 \mathrm{~cm}$ [15].

\subsubsection{Body Length}

DPFG cocks and hens had higher body length values than their respective DMFG cocks and hens. This may imply higher potential for the DPFG cocks and hens to have higher tendencies for body weight. Thus capable to yield more meat than their mixed genetic grade guinea cocks and hens. Body length of the DPFG cocks and hens 
and DMFG were longer than $(22.17 \pm 0.13 \mathrm{~cm})$ the mature indigenous guinea fowl [19]. Thus, the strains have higher potential for more carcass yield compared to the native guinea fowls in the southern guinea savannah as reported by [19].

\subsubsection{Shank Length}

DPFG cocks and guinea hens had longer shanks than their respective DMFG cocks and hens. The higher shank lengths of the DPFG cocks and hens are indication of purity of the commercial line compared to the DMFG that had been crossbred by the genetic resources of the indigenous strain. Thus, indicating the DPFG to support higher body weight. DPFG cocks and hens had longer shank length than the domesticated pearl grey guinea cocks $(7.0 \mathrm{~cm})$ and guinea hens $(7.1 \mathrm{~cm})$ reported by [21]. DPFG cocks had longer shanks than that of the indigenous guinea fowls [19] while counterpart guinea hens had relatively lower mean shank length.

The DMFG had shorter shank than $9.03 \pm 0.09,8.85 \pm$ 0.09 and $8.93 \pm 0.08 \mathrm{~cm}$ of the indigenous pearl, ash and black guinea fowls [20]. The lower shank length values of the dual purpose mix genetic grade guinea cocks and hens could be attributed to loss in vigour due to cross breeding with the local breeds.

The DMFG had longer shanks over counterpart indigenous guinea fowl $(7.73 \pm 0.08 \mathrm{~cm})$ in the southern guinea savannah [15] and $7.0-7.1 \mathrm{~cm}$ for Pearl grey guinea fowl [21]. This may be as a result of genetic upgrade that gave rise to crossbreed that had longer shanks than the local strain.

\subsubsection{Thigh Length}

The DPFG cocks had similar thigh length with the DMFG cocks but the DPFG hens had higher average thighs than DMFG hens. Thigh length of the dual purpose guinea cocks was relatively closer to the mean thigh lengths of the ash and the black plumage colours $(13.68 \pm 0.06$ and 13.66 $\pm 0.08 \mathrm{~cm})$ and $(13.89 \pm 0.06 \mathrm{~cm}$.) for the pearl indigenous guinea fowls [20]. The DPFG cocks and hens DMFG had longer thigh lengths than indigenous guinea fowl (11.87 \pm $0.10 \mathrm{~cm}$ ) in the southern savannah [19].

\subsubsection{Keel Length}

The DPFG cocks and hens had longer keels than their respective mixed genetic grade. The DPFG cocks had longer keel than mature indigenous guinea fowls in the southern guinea savannah, Nigeria [19] whereas counterpart DPFG hens had their keel length closer to the value $12.96 \pm 0.03 \mathrm{~cm}$ reported by [19]. Thus, indicating that the DPFG cocks had longer body frame than indigenous guinea fowls. The DMFG cocks had longer keel length than $(12.96 \pm 0.03 \mathrm{~cm})$ the indigenous guinea fowls [15].

\subsubsection{Neck Length}

The DPFG cocks and hens had lower average neck lengths than the Nigerian indigenous guinea fowl in the southern guinea savannah is $17.03 \pm 0.10 \mathrm{~cm}$ [15]. Mature guinea fowl cocks had longer neck than the range $16.63 \pm$ $0.19-16.69 \pm 0.19 \mathrm{~cm}$ reported by [22] whereas counterpart guinea fowl hens had average neck length closer to the range values. The differences obtained in neck length could be due to strain, sex and environmental effect as factors that affected neck length.

The DMFG cocks and hens had lower neck length than the value for indigenous guinea fowl in the southern guinea savannah, Nigerian [19]. The lower neck length of the strain could be due to differences in genotype and environment since the local strains which still possessed their attribute of longer necks that is paramount for foraging and defence against predators.

\subsubsection{Wing Span}

The DPFG and the DMFG cocks and hens had longer wing span than adult indigenous guinea fowls $19.34 \pm 0.21$ $\mathrm{cm}$ by [19] and those of indigenous ash, pearl and black guinea fowls [20] but shorter than wing span values $(60.10$ \pm 1.70 and $56.70 \pm 1.70 \mathrm{~cm}$ ) for pearl grey guinea cocks and hens [23]. The differences may be due to strain effects. Longer wing span of the DPFG and the DMFG over that of the local strain indicates genetic superiority of strains toward body appendages.

\subsubsection{Wattle Length}

The wattle length of the DPFG cocks and hens were higher than wattle length of the DMFG cocks and hens respectively. Wattle length of the DPFG cocks and hens were longer than the wattle length of helmeted guinea fowl reported by [24] and those of the pearl grey guinea fowl [23]. The longer wattles of the strain could be a pointer for variations due to strain effect and a strain developed with higher efficiency for body temperature dissipation since wattle are medium for body temperature regulation in birds.

The average wattle length of the DMFG cocks and hens were higher than the average of the pearl grey guinea fowls by [23]. Thus, it could be inferred that the strain could have better medium for heat dissipation due to crossbreeding of the local strain with the pure grade guinea fowls.

\subsubsection{Head Length}

DPFG cocks and hens had longer head than their respective DMFG cocks and hens. The DPFG cocks and hens had longer heads than $(6.48 \pm 0.50 \mathrm{~cm})$ the wild type guinea fowl in Kenya [25]. This may be due to selection for the trait while breeding for improved body weight and egg number over wild guinea fowls.

The DMFG had longer head length $(6.48 \pm 0.50)$ than the wild type guinea fowl [25]. Higher head length of the DMFG over the head length of the wild type guinea fowl could be as a result of derived advantage due to crossbreeding. 


\subsubsection{Helmet Length and Thickness}

Helmet length of the DPFG cocks and hens were lower than those of DMFG cocks and hens. This difference could be due to strain and the genome of birds that favours the expression of longer helmet among the DMFG.

Helmet length and thickness of the DMFG were higher than $0.52 \pm 0.03$ and $0.47 \pm 0.03 \mathrm{~cm}$ (helmet length) and $0.52 \pm 0.03$ vs. $0.47 \pm 0.03 \mathrm{~cm}$ (helmet thickness) reported by [23] but lower than $2.57 \pm 0.40 \mathrm{~cm}$ by [24] and $2.8 \pm$ 0.36 and $2.2 \pm 0.24 \mathrm{~cm}$ [26]. Differences in helmet length and thickness due to sex effect among guinea fowl cocks and guinea hens agreed with [27] who informed that helmet length of guinea fowl cocks is higher than helmet length of counterpart guinea fowl hens. Similar trend was also observed by [26].

\subsubsection{Beak Length}

DPFG cocks and hens had longer beak than the DMFG cocks and hens respectively. Longer average beak length of the DPFG may be an indication of dilution of the genome that governs the expression body structures in the DMFG by crossbreeding with the local strain.

\subsubsection{Tail Length}

The DPFG cocks had longer tail than the DMFG a cocks but strain had no effect on tail length among guinea hens. Mean tail lengths of the DPFG cocks and hens as well as those of the DMFG cocks and hens were higher than tail length of the pearl grey guinea fowl reported by [23]. This variation could be as a result of differences in the genetic make-up that promotes longer tail length expression of the investigated strains.

\section{Conclusions}

The DPFG cocks had higher body weight and body linear traits than counterpart DMFG cocks except thigh length (both strains were similar) and the helmet length, DMFG cocks were significantly higher.

The DPFG hens had higher body weight and all body linear traits than counterpart DMFG hens except tail length (both strains were similar) and the helmet length, DMFG hens were significantly higher.

The crossbreeding of the DPFG hens with local indigenous guinea fowl cocks had resulted to a reduction in body weight and body linear measurements among the DMFG. Losses in vigour of traits evaluated were below fifty percent except the helmet thickness of the DMFG.

\section{Recommendations}

The dual purpose French guinea fowls and their mixed genetic grade had higher body weight than all local guinea fowl strains reviewed. Hence, introduction of the dual purpose French guinea fowl strain among farmers in
Nigeria may yield higher body weight than local guinea fowls.

Further studies should be carried out in order to investigate the performance of the dual purpose French guinea fowl strain and their Mixed genetic grade in terms of growth rate, heterosis of first filial generation and the best combining ability.

\section{REFERENCES}

[1] Mwale M, Mupangwa J. F., Mapiye C. (2008). Growth performance of guinea fowl keets fed graded levels of Baobab Seed Cake diets. International Journal of Poultry Science, 7(5): 429-432

[2] Obike, O. M., Oke, U. K. and Azu, K. E. (2011). Comparison of Egg Production Performance and Egg Quality Traits of Pearl and Black Strains of Guinea Fowl in a Humid Rain-Forest Zone of Nigeria. International Journal of Poultry Science, 10 (7): 547-551, 2011 ISSN 1682-8356

[3] Gwaza, D. S. and Elkanah, H. (2017). Evaluation of body weight and body linear measurements of broad and narrow helmeted French broiler guinea fowl in the semi-arid condition of Nigeria. Journal of Research Report on Genetics. 1(1):7-12

[4] Dieng, A., Gue'ye, E. F., Mahoungou-Mouelle, N. M. and Buldgen, A. (1998). Effect of diet and poultry species on feed intake and digestibility of nutrients in Senegal. International Network Farm. Poultry Development Newsletter, 8:4-9

[5] Nahashon, S.N., Aggrey, S. E., Adefope, N. A., Amenyunu, A., Wright, D. (2006a). Growth characteristics of Pearl Gray Guinea fowl as predicted by the Richards, Gompertz and Logistic Models. World's Poultry Science Journal, 85 359-363

[6] Nahashon, S. N., Aggrey, S. E., Adefope, N. A. and Amenyenu, A. (2006b). Modeling Growth Characteristics of Meat-type Guinea fowl. World's Journal of Poultry Science, 85:943-946

[7] Happyson, S. (2005). Guinea Fowl Production under smallholders farmers management in Guruve District Zimbabwe. M. Sc. Thesis, Department of Animal Science University of Zimbabwe

[8] Wikipedia (2013). Nigeria Wikipedia the free encyclopedia. Retrieved online 21/09/2016

[9] The Encyclopedia Britannica Online (2007). Koppen Climate Classification. Retrieved online 21/09/2016

[10] Sunmap.eu.net (2011). Retrieved on $12^{\text {th }}$ Oct., 2016

[11] FAO (2011). A Draft Guidelines on Phenotypic Characterization of Animal Genetic Resources in Commission on Genetic Resources for Food and Agriculture. 13th Regular Session. Rome, 18 - 22 July 2011. Accessed on 12/07/2016 http://www.faostat.org

[12] SPSS. 21. Statistical Package for Social Sciences. Chicago, SPSS Inc., 444 Michigan Avenue, IL60611 
154 Evaluation of Loss in Vigour of the Dual Purpose French Guinea Fowl and Their Mixed Genetic Grade in Katsina, Nigeria

[13] Sales, J. and Du Preez, J. J. (1997). Protein andenergy requirements of the Pearl Grey guinea fowl. World's Poultry Science Journal, 53(1):382-385 Accessed on 03/09/2016 https://www.researchgate.net/publication/248626735

[14] Oke, U. K., Herbert, U. and Akinmutimi, A. H. (2003). Early lay Characteristics and Haematology of Pearl Guinea fowls as Influenced by Dietary Protein and Energy levels. International Journal of Poultry Science, 2 (2): 128-132

[15] Ogah, D. M. (2012). In Vivo Prediction Of Live Weight And Carcass Traits Using Body Measurements In Indigenous Guinea Fowl Biotechnology in Animal Husbandry 28 (1), p 137-146. Publisher: Institute for Animal Husbandry, Belgrade-Zemun

[16] Dahouda, M., Toleba, S.S., Youssao, A.K.I., Kogui, S.B., Aboubakari, S.Y. and Hornick, J.L. (2007). Guinea fowl rearing constraints and flock composition under traditional management in Borgu Department, Benin. Family Poultry, $17(1 \& 2): 3-14$

[17] Saina, H. (2005). Guinea fowl (Numidia meleagris) production under small holder farmers management in Guruive District Zimbabwe Msc Theses. University of Zimbabwe. Pp.14-34, 50

[18] Mróz, E., Tomaszewska, K., Michalik, D., Makowski, W., Stępińska1, M. and Kubińska, M. (2016). Effect of genotype, sex and age on plumage maturity, and body weight of guinea fowl (Numida meleagris). Journal of Annual Animal Science, 16(1) 245-257

[19] Ogah, D. M. (2013). Variability in body shape characters in an Indigenous Guinea fowl. (Numida Meleagris L.) Slovak Journal of Animal Science, 46, 2013 (3): 110-114

[20] Fajemilehin, S. O. K. (2010). Morphostructural characteristics of three varieties of Grey breasted Helmeted Guinea fowl in Nigeria. International journal of Morphology, 28(2):557-562

[21] Daria, K., Henryka. K. and Dariusz, K. (2011). Effect of age and sex on body weight and body dimensions of pearl (grey) guinea fowl. Journal of animal science production and zoo technical, 10(3): 39-44

[22] Nsoso, S. J., Mareko, M. H. D., Molelekwa, C. (2006). Comparison of growth and morphological parameters ofguinea fowl (Numidameleagris) raised conconcrete and earth floor finishes in Botswana. Journal of Livestock Research for Rural Development, 18,101

[23] Abdul-Rahman, I. I., Awumbila, B., Jeffcoate, I. A., Robinson, J. E. and Obese, F. Y. (2015). Sexing in guinea fowls (Numida meleagris). Journal of Poultry Science, 94:311-318 http://dx.doi.org/10.3382/ps/peu067

[24] Prinsloo, H.C., Harley, V., Reilly, B.K. and Crowe, T.M. (2005). Sex-related variation in morphology of helmeted guinea fowl (Numida meleagris) from the Riemland of the north- eastern Free State, South Africa. South African Journal of Wildlife Research, 35(1): 95-96 (April 2005)

[25] Panyako, P. M., Imboma, V., Kariuki, D. W., Makanda, M., Oyier, P. A., Malaki, P., Ndiema, E. K., Obanda, E K., Agwanda, B., Ngeiywa, K. J., Lichoti, J. and Ommeh, S. C.(2016). Phenotypic characterization of domesticated and wild helmeted Guinea fowl of Kenya. Journal of Livestock Research for Rural Development, 28 (9):1-7
[26] Venkatesan, S., Shazia N., Kannan. T. A., Sabiha, H. B. and Geetha, R. (2015). Functional morphology of the epidermal structure of the feeding apparatus of guinea fowl (Numida meleagris). International Journal of Advanced Research, 3(10): $1601-1608$

[27] Ayorinde, K. L. (2004). The Spice of Life. Presented at the Seventy-First Inaugural Lecture, Ilorin, Nigeria: University of Ilorin. 